\title{
Promosi Dan Pemeriksaan Kesehatan Sebagai Upaya Meningkatkan Produktifitas Di Masa Menopause Dan Andropause
}

\author{
Oleh \\ Dwi Yati ${ }^{1)}$ dan Sujono Riyadi ${ }^{2}$ \\ ${ }^{1,2)}$ Prodi Keperawatan, Fakultas Kesehatan Universitas Jenderal Achmad Yani Yogyakarta, \\ Jl. Brawijaya, Ambarketawang, Gamping, Sleman, Yogyakarta. \\ E-mail: dwie.ns215@gmail.com ${ }^{1)}$ dan sujono_kmpk2005@yahoo.com ${ }^{2}$
}

\begin{abstract}
Abstrak
Klimakterium sebagai suatu fase di mana terjadi peralihan antara fase reproduktif ke fase non reproduktif yang sering disebut dengan menopause. Pada masa klimakterium akan terjadi perubahan hormonal baik pada perempuan maupun laki-laki yang menyebabkan ketidaknyamanan dengan gejala seperti sakit kepala, masalah seksual, takikardi, hot flushes, berkeringat dan insomnia yang secara signifikan dapat menurunkan kualitas hidup. Tujuan dari pengabdian kepada masyarakat ini adalah untuk meningkatkan pengetahuan lansia tentang cara hidup sehat dan produktif di masa menopause dan andropause. Hasil yang didapatkan saat pelaksanaan pengabdian masyarakat ini adalah bahwa dari 58 lansia yang hadir dalam posyandu lansia di Gamping Kidul ada 73,33\% lansia laki-laki yang mengalami hipertensi dan $27,91 \%$ lansia perempuan yang mengalami hipertensi. Terdapat $26,67 \%$ lansia laki-laki yang mengalami peningkatan kadar asam urat dan $0,46 \%$ lansia perempuan yang mengalami peningkatan kadar asam urat. Saat dilakukan promosi Kesehatan berkaitan dengan pola hidup yang sehat mayoritas lansia paham untuk senantiasa menjaga kebugaran tubuh, komsumsi makanan yang sehat dan rutin berolahraga.
\end{abstract}

Kata kunci: lansia, sehat, produktif 


\section{Pendahuluan}

Peningkatan usia harapan hidup merupakan salah satu indikator keberhasilan pembangunan. Dengan meningkatnya usia harapan hidup, menyebabkan jumlah penduduk lanjut usia terus mengalami peningkatan dari tahun ke tahun. Seiring dengan peningkatan usia, banyak terjadi proses pertumbuhan dan perkembangan pada manusia, namun suatu saat pertumbuhan dan perkembangan manusia tersebut akan berhenti pada satu tahapan sehingga selanjutnya akan terjadi banyak perubahan pada fungsi tubuh manusia (Depkes, 2007). Pada proses menua akan terjadi perubahan fisik dan psikologis. Salah satu perubahan yang terjadi pada lanjut usia adalah perubahan fungsi seksualitas. Perubahan fungsi seksualitas akan terjadi pada masa klimakterium.

World Health Organization (WHO) mendefinisikan klimakterium sebagai suatu fase di mana terjadi peralihan antara fase reproduktif ke fase non reproduktif. Pada masa klimakterium ini akan terjadi perubahan hormonal baik pada perempuan maupun laki-laki. Usia perempuan ketika memasuki fase klimakterium berbeda-beda. Sebagian besar klimakterium terjadi pada usia 45-50 tahun, dengan rata rata usia 48,7 (Bairy, et al, 2009). Ada 80\% perempuan yang melaporkan bahwa terdapat ketidaknyamanan serta munculnya gejala yang terjadi saat klimakterium seperti sakit kepala, masalah seksual, takikardi, hot flushes, berkeringat, dan insomnia yang secara signifikan dapat menurunkan kualitas hidup (Blumel et al., 2000; Dennerstein, Alexander \& Kotz, 2003). Selain ketidaknyamanan fisik, sebagian besar perempuan klimakterik juga mengalami depresi. Untuk itu diperlukan proses adaptasi terhadap berbagai masalah dan perubahan selama masa klimakterium sehingga mampu meningkatkan kualitas hidup lanjut usia.

Keluhan dan adanya ketidaknyamanan ini bisa disikapi secara berbeda pada setiap orang. Apabila lansia dapat berpikir positif maka berbagai keluhan dapat dilalui dengan lebih mudah. Namun sebaliknya, apabila lansia tersebut berpikir negatif maka keluhankeluhan yang muncul semakin 
memberatkan dan menekan hidupnya. Berdasarkan informasi yang didapatkan dari kader posyandu bahwa lansia yang ada di posyandu Gamping Kidul sebagian besar tidak bekerja serta belum paham mengenai bagaimana cara tetap sehat dan produktif di masa menopause dan andropause.

Dari fenomena tersebut di atas, kami tertarik untuk memberikan penyuluhan Kesehatan sekaligus melakukan pemeriksaan Kesehatan terkait dengan upaya agar masyarakat tetap sehat dan produktif di masa menopause dan andropause. Harapannya adalah agar dapat membuat kehidupan saat menopause ini sedikit lebih mudah serta berupaya untuk membina kesehatan di usia lanjut, sehingga menjadi lansia yang sehat dan mandiri serta produktif.

\section{Metode Pelaksanaan}

Promosi dan pemeriksaan kesehatan ini dilaksanakan pada hari Senin tanggal 16 Januari 2017, jam 09.30-12.00 WIB. Metode pelaksanaan pengabdian kepada masyarakat ini dibagi ke dalam tiga tahapan.
Pada tahap pertama ini adalah tahap persiapan, mempersiapkan dari mulai perizinan melakukan kegiatan kepada kepala desa setempat. Setelah melakukan pengkajian data, mempersiapkan mulai dari materi dan media yang akan digunakan dalam promosi. Setelah persiapan teknis selesai, memberitahukan kepada lansia akan diadakannya promosi dan pemeriksaan Kesehatan untuk memantau agar senantiasa tetap sehat dan produktif di masa menopause dan andropause.

Pada tahap kedua, pelaksanaan promosi dan pemeriksaan kesehatan agar tetap produktif di masa menopause dan andropause pada lansia. Adapun metode yang digunakan dalam pendidikan kesehatan adalah ceramah dan tanya jawab yang dipandu oleh ketua tim dan anggota tim, sebelumnya dilakukan pretest, dilanjut pemeriksaan tanda-tanda vital, serta pemeriksaan asam urat. Promosi kesehatan ini diharapkan dapat meningkatkan pengetahuan lansia tentang cara hidup sehat dan tetap produktif di masa menopause dan andropause, sehingga diharapkan ada 
perubahan perilaku bagi lansia dalam kehidupan sehari-hari.

Tahap ketiga adalah evaluasi akhir untuk melihat gambaran tingkat keberhasilan dari pelaksanaan program pengabdian kepada masyarakat yang telah dilaksanakan dengan cara memberikan posttest.

Untuk lebih jelasnya dapat dilihat pada bagan berikut ini:

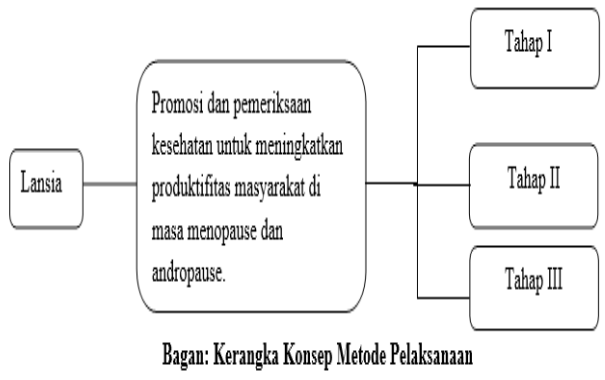

\section{Hasil Dan Pembahasan}

Kegiatan yang telah dilakukan adalah memberikan promosi Kesehatan dan pemeriksaan Kesehatan berupa pemeriksaan tekanan darah dan pemeriksaan asam urat kepada yang lansia yang hadir di Posyandu. Lansia yang hadir sebanyak 58 orang lansia.

Adapun hasil kegiatan yang telah dilakukan berkaitan pengecekan tekanan darah dan pemeriksaan kadar Asam Urat adalah sebagai berikut.
Tabel 1. Distribusi Frekuensi Lansia berdasarkan Jenis Kelamin

\begin{tabular}{c|c|c}
\hline Jenis Kelamin & N & \% \\
\hline Laki- Laki & 15 & 25,86 \\
Perempuan & 43 & 74,14 \\
\hline Total & $\mathbf{5 8}$ & $\mathbf{1 0 0}$ \\
\hline
\end{tabular}

Sumber: Data Primer

Pada Tabel 1 diatas mayoritas lansia yang ada di Gamping Kidul adalah perempuan yaitu ada $74,14 \%$, sedangkan $25,86 \%$ adalah lansia lakilaki.

Tabel 2. Tekanan Darah Lansia di Posyandu Gamping Kidul

\begin{tabular}{lcccc}
\hline \multirow{2}{*}{ Jenis kelaminin } & \multicolumn{4}{c}{ Tekanan Darah } \\
\cline { 2 - 5 } & Hipertensi & $\%$ & Normal & $\%$ \\
\hline Laki-laki & 11 & 73,33 & 4 & 26,67 \\
Perempuan & 12 & 27,91 & 31 & 72,09 \\
\hline
\end{tabular}

Sumber: Data primer

Berdasarkan Tabel 2 diatas didapatkan hasil bahwa lansia yang mengalami hipertensi secara jumlah banyak perempuan yaitu ada 12 lansia $(27,91 \%)$. Namun apabila dilihat dari segi prosentase justru banyak laki-laki yaitu sebanyak 73,33\%.

\section{Tabel 3. Kadar Asam Urat Lansia di Posyandu Gamping Kidul}




\begin{tabular}{lcccc}
\hline \multirow{2}{*}{ Jenis kelamin } & \multicolumn{4}{c}{ Kadar Asam Urat } \\
\cline { 2 - 5 } & Tinggi & $\%$ & Normal & $\%$ \\
\hline Laki-laki & 4 & 26,67 & 11 & 73,33 \\
Perempuan & 2 & 0,6 & 41 & 95,34 \\
\hline
\end{tabular}

Sumber: Data primer

Berdasarkan Tabel 3 tersebut didapatkan hasil bahwa lansia yang mengalami peningkatan kadar asam urat banyak lansia laki-laki yaitu ada $26,67 \%$, sedangkan perempuan yang mengalami peningkatan asam urat ada $0,46 \%$.

Pada masa menopause dan andropause, lansia akan mengalami penurunan hormon yang akan berdampak pada munculnya berbagai keluhan dan masalah Kesehatan (Baziad, 2003 dan Lestari 2010). Andropause merupakan kumpulan gejala dan keluhan yang dialami pria sebagai akibat menurunya kadar hormon testosteron. Andropause terjadi pada pria di atas usia tengah baya yang mempunyai kumpulan gejala yang mirip dengan menopause pada wanita (FK UI, 2013). Salah satu usaha yang bisa dilakukan untuk mengatasi keluhan yang muncul adalah dengan menerapkan pola hidup sehat yang meliputi makan makanan yang sehat, cukup istirahat, olahraga teratur, hindari merokok dan alkohol, rekreasi (Emma, 2013).

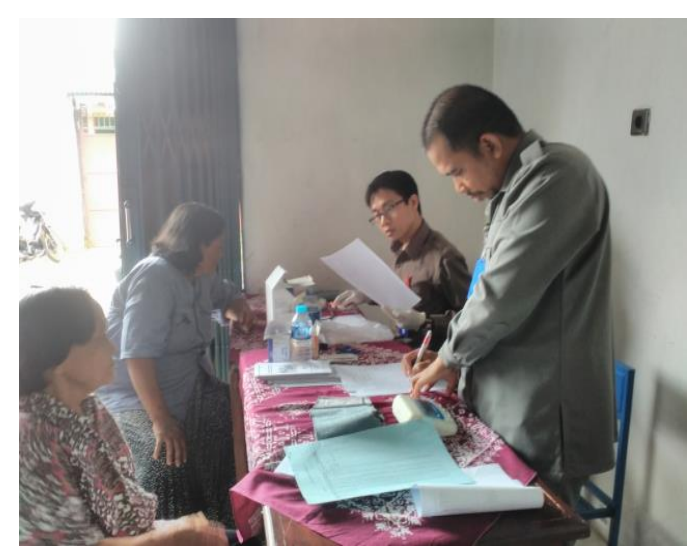

\section{Gambar 1: Pemeriksaan Kesehatan}

Lansia yang menerapkan pola hidup sehat akan mampu untuk tetap produktif serta berperan aktif di masyarakat tanpa harus membebani keluarganya (Sulandari et al., 2009 dan Fadilla, 2015). Perempuan menopause harus rendah lemak jenuh dan kolesterol tetapi harus tinggi karbohidrat yang kompleks seperti biji bijian, buah, dan sayur (Pakasi, 2000). 


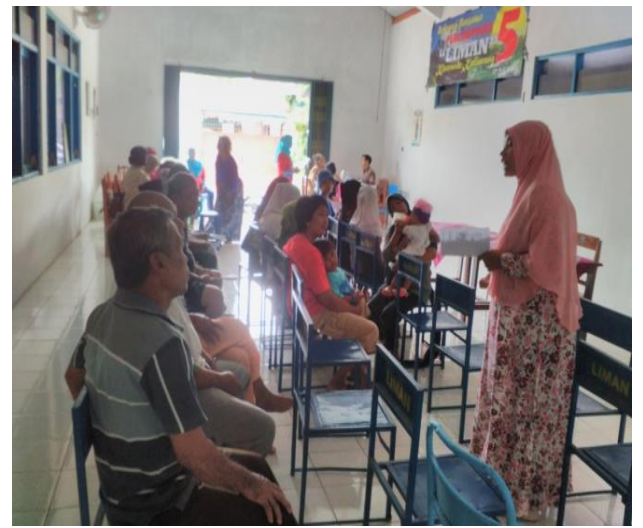

Gambar 2: Pemberian Promosi Kesehatan

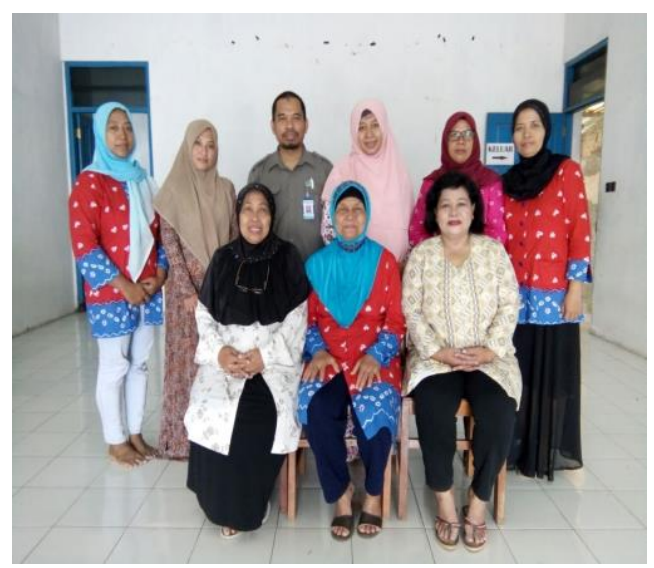

Gambar 3: Foto Bersama Kader Posyandu Kesehatan

\section{Kesimpulan}

Pada pelaksanaan pengabdian masyarakat ini, dari 58 lansia yang hadir dalam posyandu lansia di Gamping Kidul ada sejumlah 73,33\% lansia laki-laki yang mengalami hipertensi dan 27,91\% lansia perempuan yang mengalami hipertensi. Terdapat 26,67\% lansia laki-laki yang mengalami peningkatan kadar asam urat dan $0,46 \%$ lansia perempuan yang mengalami peningkatan kadar asam urat. Saat dilakukan promosi Kesehatan berkaitan dengan pola hidup yang sehat mayoritas lansia paham untuk senantiasa menjaga kebugaran tubuh, komsumsi makanan yang sehat dan rutin berolah raga.

\section{Saran}

Bagi Lansia: diharapkan semua lansia selalu menerapkan pola hidup yang sehat agar kesehatan di usia lanjut tetap terjaga secara optimal sehingga mampu tetap produktif dan bermanfaat bagi masyarakat.

Bagi kader Posyandu Gamping Kidul: diharapkan dapat secara kontinyu mengadakan penyuluhan Kesehatan terkait permasalahan yang muncul pada lansia.

\section{Ucapan Terima Kasih}

Terima kasih kami ucapkan kepada Kuswanto Hardjo, dr, M. Kes selaku Dekan Fakultas Kesehatan Universitas Jenderal Achmad Yani Yogyakarta.

\section{Daftar Pustaka}


Bairy, L., Adiga, S., Bhat, P., Bhat, R. (2009). Prevalence of Menopausal Symptoms and Quality of Lufe after Menopause in Women from South India. Australian and New Zealand Journal of Obstetric and Gynaecology. 49: 106-109

Baziad, A., (2003). Menopause dan Andropause. Yayasan Bina Pustaka Sarwono Prawirohardjo. Jakarta.

Blumel, J.E., Branco, C.C., Binfa, L., Gramegna, G., Tacla, X., Aracena, B. (2000). Quality of Life after the menopause: A Population Study. Maturitas, 34, 17-23

Dennerstein, L., Alexander, J.L., \& Kotz, K. (2003). The menopause and sexual functioning: A review of the population-based studies. Annual Review of Sex Research, 14, 64-82.

Departemen Kesehatan RI. (2007). Tips mempersiapkan menopause.

Emma, S.W. (2013). Agar Tetap Sehat, Cantik, dan Bahagia di Masa Menopause. Gramedia. Jakarta.

Fakultas Kedokteran Universitas Indonesia. (2013). Menopause dan Andropause. Yayasan Bina Pustaka Sarwono Prawirohardjo. Jakarta.

Fadilla R. (2015). Menuju Lansia Bahagia dan Tetap Produktif. Himpunan Psikologi Indonesia (HIMPSI).

Lestari, D. (2010). Seluk Beluk Menopause. Cetakan pertama. Graha ilmu.Yogyakarta.

Pakasi. (2000). Menopause, Masalah, dan Penanggulangannya. Edisi kedua. Fakultas Kedokteran Universitas Indonesia. Jakarta.

Sulandari S., Matyastanti D., Mutaqwarohmah R. (2009). Bentuk-bentuk Produktivitas
Lansia, Jurnal Ilmiah Berkala

Psikologi, 11 (1). 58-68 